\title{
MODERN TRENDS IN TEACHING METHODS OF LANGUAGES
}

DOI https://doi.org/10.30525/978-9934-26-180-0-46

\section{ОСОБЛИВОСТІ ВИКЛАДАННЯ УКРАЇНСЬКОЇ МОВИ У СИСТЕМІ ЛІНГВІСТИЧНОЇ ПІДГОТОВКИ ІНОКОМУНІКАНТІВ}

\author{
Абрамова I. $\Gamma$. \\ кандидат філологічних наук, \\ дочент кафедри мовної підготовки \\ Запорізький державний медичний університет \\ м. Запоріжжя, Украӥна
}

Вивчення іноземними громадянами української мови на сучасному етапі стає найбільш актуальним, що пов'язано, насамперед, 3 євроінтеграцією України, а також зі змінами суспільної свідомості.

Питанню методики викладання української мови як іноземної присвячено чимало наукових та навчально-методичних видань. Орієнтирами аналізу стали спроектовані на досліджувану проблему праці таких вчених, як 3. Бакум, Х. Бахтіярової, Л. Бєй, А. Бронської, Г. Онкович, О. Тростинської, О. Туркевич, А. Чистякової та ін.

Слушним є твердження дослідниці О. Туркевич, що «розвиток МВУМІ (методика викладання української мови як іноземної) відбувається в новій площині. Кількісне збільшення практичних матеріалів, зокрема різного типу навчальних посібників для іноземців... Крім навчальних видань, різноаспектні теоретичні питання з методики викладання української мови як іноземної висвітлено в численних наукових статтях... Процес творення навчальних видань набуває динамічності» [1, c. 34].

Проте варто відзначити, що викладання української мови іноземним громадянам в Україні пов'язане з низкою проблемних ситуацій, зокрема відсутністю підтримки з боку держави, недосконалістю методики викладання української мови як іноземної. Недостатня кількість підручників 3 української мови для студентів-іноземців гальмує 
навчальний процес. До того ж і якість навчальних видань не відповідає сучасним потребам вищої освіти.

Навчальні програми з української мови як іноземної, а також кількість аудиторних годин щороку змінюються, тому потребують належного доопрацювання освітні стандарти.

Визнаючи, що проблема українсько-російського білінгвізму стала помітною ознакою мовної ситуації, насамперед у Східній Україні, зазначимо, що іноземні студенти мають слабку мотивацію у вивченні української мови. У неформальних комунікативних ситуаціях на території міста Запоріжжя переважає спілкування російською мовою. На вулицях, у магазинах, транспорті, побутовому спілкуванні вживають російську, тому вивчення української мови стає вкрай складнішим для іноземних студентів, через відсутність відповідного мовного середовища.

Студенти висловлюють здивування, чому в Україні люди не спілкуються рідною мовою. Як бачимо, знижується ефективність вивчення української мови в умовах білінгвізму, обмежується відповідний лексичний запас іноземних громадян.

Запорізький державний медичний університет відкриває нові можливості іноземним студентам для пізнання і вивчення української мови, культури, історії, літератури. Кафедра мовної підготовки застосовує у процесі викладання української мови як іноземної матеріали 3 українознавства, що допомагає іноземцям адаптуватися до нового мовно-культурного середовища.

Враховуючи комунікативні потреби індійських студентів англомовної форми навчання, викладачі ретельно підбирають різноманітні тексти, у яких можна познайомитися з досягненнями української й індійської науки та культури, прочитати про визначних людей України та Індії у сфері науки, культури, спорту. Використання таких матеріалів стимулює мотивацію іноземних студентів, посилює інтерес до навчання.

Не можна не погодитись із думкою дослідниці 3. Бакум, що «основною метою в навчанні української мови як іноземної $є$ комунікативна, яка визначає увесь навчальний процес, що викликає необхідність реалізації комунікативно-діяльнісного підходу - вивчення мови як засобу спілкування у процесі взаємопов'язаного та цілеспрямованого вдосконалення чотирьох видів мовленнєвої діяльності студентів - аудіювання (слуханнярозуміння), читання, говоріння, письма» [2, с. 228].

Аудіювання $є$ важливою складовою мовної діяльності, тому його застосування у системі лінгвістичної підготовки іноземних громадян $\epsilon$ вкрай необхідним. «Аудіювання (лат. audire - слухати) - рецептивний вид мовленнєвої діяльності, слухання, смислове сприйняття усного 
повідомлення. Складається із сприйняття мовної форми і розуміння змісту повідомлення», - зазначає дослідник Ф. Бацевич [3, с. 337].

Навчання аудіюванню на кафедрі мовної підготовки ЗДМУ неможливе без аудіативних умінь і навичок, що є невід'ємним компонентом компетентності інокомунікантів. Особлива увага приділяється виявленню вмінь адекватно сприймати, логічно осмислювати інформацію текстів описового характеру з елементами діалогу навчально-побутової тематики: «Моя родина», «Мій університет», «Мій гуртожиток», «Мої друзі» тощо.

Спираючись на досвід викладання української мови іноземним громадянам Індії (англомовної форми навчання), зазначимо, що постає складна проблема - важко навчити їх правильно говорити по-українськи. Це пояснюється насамперед відсутністю україномовного середовища, а також відмінними ознаками фонетичної системи, граматичної будови та лексичного складу української та індійської мов (хінді, телугу та ін.), зокрема на характеристиках звуків, форм слів відповідно до орфоепічних та орфографічних літературних норм.

Щоб зробити традиційні заняття цікавими, підвищити ефективність вивчення української мови, викладачі кафедри мовної підготовки ЗДМУ використовують різні інноваційні підходи: репрезентують аудіо матеріали, відеозаписи, рольові ігри, перегляд новин, телепередач, документальних та художніх фільмів українською мовою.

Активізації пізнавальної діяльності індійських студентів під час вивчення української мови як іноземної сприяє їх участь у різних конкурсах, наприклад, конкурсі читців - «Поезія - свобода серця», «Кращий знавець українських традицій, звичаїв, обрядів» тощо.

Особливо ефективними $є$ виїзні заняття з української мови. У межах вивчення теми «Запоріжжя, в якому я живу і навчаюсь», індійські студенти знайомляться з історією міста, відвідують відомі запорізькі пам'ятки.

Варто відзначити, що найбільш складною для сприйняття іноземними студентами є тема «Дієприкметник та дієприслівник як форми дієслова». Як зазначає Л. Губа, «вмотивованість викладача, його бажання надати актуальну і корисну інформацію, оформлену за допомогою лексикограматичних конструкцій, мотивує студентів до опанування фаховими знаннями через вивчення мови. Тоді навіть такі надскладні теми, як дієприкметник i дієприкметниковий зворот чи складнопідрядні синтаксичні конструкції, будуть актуалізовані у когнітивній діяльності студента» $[4$, с. 21$]$.

Для кращого засвоєння такого матеріалу викладачі кафедри обирають наукові тексти за професійним спрямуванням, а саме: медичним, 
стоматологічним, фармацевтичним (з використанням дієприкметникових та дієприслівникових форм). Це сприятиме поглибленому вивченню навчального матеріалу і допоможе іноземним громадянам у майбутній професійній діяльності за фахом.

Отже, викладачі кафедри мовної підготовки ЗДМУ намагаються створити сприятливі умови для вивчення української мови іноземними студентами, для подальшого іiі використання у сферах громадського життя, у повсякденному спілкуванні, для набуття знань у професійній діяльності. Але успішне виконання цих завдань значною мірою зумовлено координацією дій закладів вищої освіти та міністерства освіти України.

\section{Література:}

1. Туркевич О. В. Становлення терміносистеми методики викладання української мови як іноземної: монографія, Львів : ЛНУ імені Івана Франка, 2015. 220 с.

2. Бакум 3. П. Українська мова як іноземна: лінгводидактичні проблеми. Філологічні студії. Науковий вісник Криворізького державного педагогічного університету. Випуск 5, 2010. С. 226-232.

3. Бацевич Ф. С. Основи комунікативної лінгвістики: підручник. К. : ВЦ «Академія», 2009. 376 с.

4. Губа Л. Проблеми мотивації іноземних студентів на заняттях 3 української мови. Актуальні проблеми навчання іноземних студентів. Матеріали XXII Всеукраїнської науково-практичної конференції. Дніпро, 2020. C. $20-22$. 